\title{
The Strategy of School Principal in Improving the Teachers Performance
}

\author{
Syukur Manto ${ }^{1 *}$, Yasir Arafat ${ }^{2}$, Yenny Puspita ${ }^{2}$
}

\author{
${ }^{I}$ SMK Negeri 2 OKU Selatan \\ ${ }^{2}$ Universitas PGRI Palembang \\ *Corresponding Author. Email: Syukurmanto8@gmail.com
}

\begin{abstract}
A principal is a functional teacher position who is assigned the task of leading a school. The effective role of the principal will certainly affect teacher performance. This study is aimed to find out the strategies implemented by the principal of Vocational High School State 2, Oku Selatan, in improving teachers performance in that school. This qualitative study used observation, interviews, and documentation for collecting the data. The data were collected in the form of words, written, or oral from the observed object (the principal, teachers and students). The results showed that the principal had an effective strategy in improving teacher performance which included coaching, supervision, disciplinary development, giving motivation, and giving rewards.
\end{abstract}

Keywords: Principal, Strategy, Teacher Performance.

\section{INTRODUCTION}

Education is concerned with social interactions both directly and indirectly in human life. Guidance, teaching and training activities are educational activities that are carried out consciously and last a lifetime. Education makes people smart, wise and has the ability to adapt in the family environment and in the social environment, so that good cooperation is established between one another [1].

Education in the current era of globalization is marked by very fierce competition both in terms of knowledge and in terms of technology. The development of science and technology requires people to learn continuously, especially for people who have high dedication such as a teacher. Therefore a teacher must constantly improve the quality of teaching both strategies and knowledge and skills.

The Ministry of National Education always strives to make various changes and reforms in the field of the education system. One example of the efforts that have been and are being carried out by the government is related to the quality factor of teacher performance [2]. In fact, teachers do not easily carry out their duties and develop their potential because they are faced with various problems in their lives and the lack of facilities they provide in teaching so that they carry out their duties as an educator in providing subject matter to students is not accompanied by thorough preparations, let alone adding insight and knowledge from other sources so that it will lead to unproductive performance of educators [3]. Another problem that arises is that there are still many teachers who have not been optimal in carrying out their duties, among them there are still many teachers who have not made a learning implementation plan, incompatibility in the use of teaching methods, and teacher unpreparedness in teaching.

The principal must be able and have a plan in determining teacher performance development strategies that lead to professional improvement of teacher performance. The achievement of teacher performance depends very much on the abilities and skills and leadership of the principal, because the principal has full responsibility in positioning his human resources gradually and continuously so as to achieve the set performance standards [4].

To achieve the goals that have been determined collectively, the principal must be able and wise in fostering teaching and administrative personnel, in his performance the principal can directly help the performance of teachers in developing their abilities to achieve the learning goals set for students and also increasing knowledge and teaching skills as well as providing guidance for teachers who experience difficulties. To be able to get good teacher performance, the principal must carry out direct and continuous supervision, in accordance with the 
principal's work principle in educational guidance [5].

The Vocational High School State 2, OKU Selatan, is one of the high schools in Ogan Komering Ulu Selatan. Various efforts to improve teacher performance has been carried out by the principal, such as training conducted at the school, district, and even provincial levels, by providing guidance related to teacher performance, adding books and learning media to support process activities and effective teaching and learning, adding practice facilities and increasing community participation in schools in supporting school programs.

Based on the observations at vocational High School 2, OKU Selatan, the writers found that some teachers are still less disciplined in starting and ending the learning process activities, there are also teachers who have not used the teaching implementation plan, teachers are also less disciplined in obeying existing regulations such as rules in collection of lesson plans. Therefore, the principal must have the right strategy in accordance with the characteristics of the teachers in the school.

\section{METHODS}

This research was conducted by means of interviews and observations which took place in Sipatuhu Village, Jalan Sukanan, Banding Agung District, South OKU Regency. In qualitative research, data collection is carried out in natural settings, primary data sources, and more data collection techniques are observation, in-depth interviews and documentation [6]. In this study, the data analysis technique used a qualitative descriptive interactive model from Milles, the primary data obtained through interviews, observations, and secondary data were processed qualitatively. Milles and Huberman [7] suggest that research data analysis consists of three concurrent activity paths, namely: (1) data reduction, (2) data presentation, and (3) drawing conclusions. At the start of data collection, the focus of the researchers was wide and unclear. Meanwhile, observations are still general and broad. After the focus became clearer, the researchers conducted more structured observations to obtain data about the principal's strategies in improving specific teacher performance. The data are then interpreted as research findings.

\section{RESULTS AND DISCUSSION}

Vocational high school education system is very different from general high school because the vocational education system emphasizes a dual education system, namely theoretical education and practical education. At Vocational High School 2, OKU selatan, practical education has started from class $\mathrm{X}$, but the practical capacity will vary according to grade level, Class $\mathrm{X}$ practical education is up to $25 \%$, class XI practical education reaches up to $50 \%$ while class XII $75 \%$, and in class XI students are required to take part in the Field Work Practice Program.

In this study, the researcher used qualitative research data, which means that the data presented was narrative which was developed in the form of questions given to informants in the form of interviews. This research was conducted from 22 October 2020 to 22 November 2020. In the data collection process, interviews were conducted with the principal, head of administration, teachers and students and were carried out separately and differently. According to the castet, there are 5 ways the principal can improve teacher performance, namely: 1. Teacher performance development, 2. Teacher discipline development, 3. Supervision or supervision of teacher performance, 4 . Motivation, 5. Awarding.

Based on the research results, it was found that the principal's strategies in improving teacher performance were as follows:

a. Through teacher performance guidance by including teachers to take part in training both held at the district and provincial levels.

b. Supervision of teacher performance, in this activity the principal directly supervises the class to see teacher performance in the learning process and immediately sees the completeness of the teacher administratively.

c. Fostering the discipline of educational personnel by monitoring the presence of teachers directly by welcoming the presence of teachers and students at the gate, so that the teacher's presence can be monitored maximally and this is done continuously.

d. In terms of motivation, the principal has provided motivation to teachers who are considered to have decreased performance in the hope that after being motivated, the teacher's performance will grow more enthusiastic so that the objectives of learning will be achieved.

e. Giving awards to teachers by giving in the form of gratitude and award certificates, this was done by the principal with the aim of motivating teachers to improve their performance.

According to Castetter's Theory, quoted by Mulyasa [8], teacher performance coaching is grouped into 3 coaching groups, the first coaching groups of teachers in classroom teaching programs, second, coaching teacher groups to assess and revise 
causes that affect student learning, the third coaching teacher groups to always improve student learning situations.

From the results of interviews with several research objects and compared with the theory according to Castetter in E. Mulyasa's quote, namely:

a. In coaching the performance of teachers, they are grouped into three parts of coaching, namely, firstly, the development of teachers' abilities in terms of maintaining teaching programs in the classroom, the second is the ability of teachers in terms of assessing and improving the factors that affect student learning, thirdly improving the learning situation of students. In terms of fostering the ability of teachers in maintaining classroom teaching programs, the principal must understand the stages of the teaching process so that it can help the principal to carry out coaching for teaching programs to teachers [9].

b. Supervision or supervision of teacher performance through learning activities, one of the efforts to improve teacher professionalism, needs guidance from the principal through academic supervision, the quality of teacher teaching can directly or indirectly affect the quality of student learning, therefore it is necessary to provide follow-up guidance from the principal, among others through teaching supervision.

c. Fostering the discipline of educational personnel in improving teacher performance, the principal must be able to cultivate the discipline of educational personnel, especially self-discipline, in this case the principal must be able to do things, namely helping education personnel develop patterns of behavior, helping educational staff increase their standard of behavior, using the implementation of rules as a tool.

d. Giving motivation to improve work productivity performance needs to be considered the motivation of educational staff and other factors that influence it. The motivation given can be in the form of rewards, educational scholarships, assignments, promotion of teacher performance. Teachers will be even more active in improving their performance if there is motivation or encouragement from the principal, this can be in the form of guidance or with verbal encouragement.

e. Giving awards is very important to increase work productivity and to reduce unproductive activities, through this appreciation, educational staff are stimulated to increase positive and productive performance. The principal who understands the needs of a teacher will provide encouragement so that the teacher can improve their performance, this can be by increasing salary, promotion, finance, charter, and must be adjusted to the assignment given and the teacher's performance results [8].

Based on the facts in the field, the researchers found that the principal's strategy in improving teacher performance was in accordance with the above theory and the principal was still trying to improve the performance of teachers by updating the strategies that had been previously set. According to Rusyan [10], teacher performance is carrying out the learning process both in the classroom and outside the classroom in addition to doing other activities, such as doing school administration and learning administration, implementing guidance and services to students, and carrying out assessments. Based on the above statement, researchers can conclude that good teacher performance must work in accordance with existing procedures starting from planning, strategy, environment, communication and evaluation.

Based on the results of interviews about teacher performance, it can be seen that the teacher's performance has started to improve. This can all be seen from the increasing level of teacher discipline, every year the students interest always increases. The principal is still trying to improve the performance of teachers by facilitating teachers in carrying out their duties, monitoring in the collection of lesson plans, more disciplining teachers and optimizing the teaching and learning process of teachers so that teachers are more professional in implementing their job.

It is said that the teacher's performance is good, this is in accordance with the competence of teachers according to the theory of Jamil Supentangininggrum, teachers are required to have competencies which include pedagogical competences, namely abilities related to student understanding and management of student learning, personality competencies, namely personal abilities that reflect (solid personality, stable, mature, wise, and dignified, being role models for students, and having noble character), social competence, namely the ability of educators as part of society to communicate and mingle effectively with students and the surrounding community, professional competence, namely abilities related to mastery of material learning the field of study broadly and deeply which includes mastery of material in the process through professional education.

With regard to teacher performance, Law No. 14 of 2005 Chapter IV Article 20 concerning Teachers and Lecturers states that the standard of teacher work performance in carrying out their 
professional duties, teachers are obliged to plan learning, carry out a quality learning process and assess and evaluate learning outcomes.

Based on the principal's strategy in improving teacher performance and the obstacles faced by the principal in improving teacher performance, there are several solutions that can be done regarding the principal being the highest leader in a school both public and private. The principal as a leader seeks to minimize the obstacles faced by schools in improving teacher performance. At the Vocational High School 2 , OKU Selatan, the principal has several solutions in improving teacher performance, including:

a) The principal's strategy in improving teacher performance in the fields of Development, Supervision, Discipline, Motivation and rewards are carried out continuously and even more;

b) In financial matters the principal must be able to consider which activities should be prioritized according to needs;

c) In dealing with teaching staff who are on average honorary status, the principal must continue to coordinate with the relevant agencies for additional teachers / staff with permanent status.

Efforts that can be made by school principals in improving teacher performance are related to their role as education leaders in schools are: (1) maximizing focus on improving teacher competence, (2) allocating sufficient budget to improve teacher professionalism, (3) providing advice and professional guidance to teachers, (4) creating a conducive school organizational culture; (5) creating renewal and excellence, and (6) providing rewards for teachers who are successful or perform well. Referring to Castetter's opinion, he explained that there are five ways the principal can improve teacher performance 1. Teacher Performance Development 2. Supervision or Supervision of Teacher Performance 3. Discipline Development 4. Motivation 5. Awards.

In accordance with the results of research conducted by [3], they found that 1) the principal management process in improving teacher performance through several stages, namely, planning, organizing, directing, and controlling. At least there are 6 things the principal does in managing a school, including curriculum management, student affairs, personnel, facilities and infrastructure, finance, and society. The principal's efforts to improve the performance of honorary teachers, especially in improving personal and professional competences.

\section{CONCLUSION}

The principal's strategy in improving teacher performance at the Vocational High School 2, OKU Selatan, can be concluded as follows: The strategy for improving teacher performance carried out by the principal of the Vocational High School 2, OKU Selatan, shows positive and good and efficient results, in this case it can be seen from the steps- The steps and efforts that have been carried out include: Coaching, Supervision, Discipline, Motivation and awards. Indicators of teacher performance development begin with teacher participation in training both at district and provincial levels. With these activities, the quality of teacher performance increases. In this coaching the principal always coordinates with the other school principals in OKU Selatan. Supervision of the principal carried out directly by the principal by entering the classroom during the teaching and learning process, in this case the principal can immediately see the teacher's performance. In developing the discipline of teachers of the Vocational High School 2, OKU Selatan, it is already good, this can be seen from the arrival of the teacher earlier compared to the arrival of the students, this is all a reflection of the good teacher the principal in providing motivation to the teachers of the Vocational High School 2, OKU Selatan, is done at the hour empty in the teacher's room, with this motivation it is hoped that teacher performance will always increase. In providing principal motivation by taking a familial approach, the principal's final strategy in improving teacher performance is by giving awards. In this strategy, the principal gives an award in the form of a charter considering the financial condition of the school, because $90 \%$ of the teachers of the Vocational High School 2, OKU Selatan, have a permanent status.

\section{REFERENCES}

[1] H. Engkoswara, Aan Komariah., \& Riduwan. (2012). Administrasi Pendidikan, Bandung: Alfabeta CV

[2] Depdiknas. (2006). Permendiknas No 22 Tahun 2006 Tentang Standar Isi. Jakarta : Depdiknas.

[3] Fitria., Fitria, H., \& Martha, A. (2020). Manajemen Kepemimpinan Kepala Sekolah dalam Meningkatkan Kinerja Guru Honorer. Journal of Innovation in Teaching and Instructional Media, 1(1), 85-89. Retrieved from

https://ejournal.karinosseff.org/index.php/jitim/ article/view/34

[4] Khasanah, U., Kristiawan, M., \& Tobari. (2019). The Implementation of Principals' Academic Supervision In Improving Teachers' Professionalism in the State Primary Schools. 
International Journal of Scientific \& Technology Research, 8(8).

[5] Atmodiwiryo Soebagio. (2011). Manajemen Pengawasan dan Supervisi Sekolah, Jakarta: PT. Ardadizya Jaya.

[6] Sugiyono. (2009). Metode Penelitian Kuantitatif, Kualitatif dan $R \& D$, Bandung: Alfabeta.

[7] Milles, M. B., \& Huberman, A. (2007). Analisis Data Kualitatif.Jakarta: Universitas Indonesia.
[8] Mulyasa. (2007). Menjadi Kepala Sekolah Profesional, Bandung: Remaja Rosdakarya.

[9] Undang-undang Republik Indonesia Nomor 14 Tahun 2005 dan Peraturan Pemerintah Nomor 74 Tahun 2008 Tentang Guru dan Dosen, Bandung: Citra Umbara.

[10] Tabrani Rusyan. (2000). Upaya Meningkatkan Budaya Kinerja Guru, Cianjur: CV. Dinamika Karya Cipta. 